\title{
SLOW SCHOLARSHIP IN WRITING RETREATS: A DIFFRACTIVE METHODOLOGY FOR RESPONSE-ABLE PEDAGOGIES ${ }^{1}$
}

\author{
V. Bozalek \\ Director of Teaching and Learning \\ University of the Western Cape \\ Cape Town, South Africa \\ e-mail: vbozalek@uwc.ac.za
}

\section{ABSTRACT}

The corporatization of universities has led to increasing pressure on academics to publish as quickly and prolifically as possible. Writing retreats have been used as one way of ensuring the production of academic articles by providing spaces for academics to write, and pressurizing them to publish shortly thereafter. This article provides an alternative way of viewing and conducting writing retreats - that of Slow scholarship, which foregrounds attentiveness, care, thoughtfulness and quality rather than quantity and production. A 'response-able' pedagogy is suggested as a way of enacting a Slow scholarship, using a diffractive methodology for reading and writing and responding to peers' writing at writing retreats.

Keywords: Slow scholarship, writing retreats, diffractive methodology, response-able pedagogies, affect

... writing is not a unidirectional practice of creation that flows from author to page, but rather the practice of writing is an iterative and mutually constitutive working out, and reworking of 'book' and 'author'. (Barad 2007, x).

There have, across differing contexts, been many hands-on and how-to texts on writing retreats for academic staff at higher education institutions (see for example Grant 2006; Moore 2003; Murray and Moore 2006; Knowles and Grant 2014; Murray 2015). While these are helpful for both retreat facilitators and participants wishing to engage with writing for publication, they do not necessarily provide readers with novel ways of re-imagining such events. Furthermore, many of these texts tend to take for granted the neoliberal conditions under which higher education is currently operating, which has led to its corporatization (Braidotti 2013; Berg and Seeber 2016; Hartman and Darab 2012; Mountz et al. 2015; Nelson and Hertz 2014; Silk, Francombe-Webb, Rich and Merchant 2015; Tabulawa 2016). This means that those involved in running such workshops tend not to question the consequent imperatives to publish as quickly and as much as possible, or recognize these as part of neoliberalism's requirements. Unfortunately, such obligations as ‘publish or perish' which are rewarded both in status and 
research funding, have the effect of occluding issues such as the quality of the published articles, as well as the amount of preparation which is needed before coming to writing retreats, and the work required after attending them. Participants who have attended writing retreats are often hounded after attending them about when and where the 'deliverable' will be published (Massumi 2015). It is almost as if a writing retreat has been appropriated as a 'fixit' solution for these purposes, and become part of the endeavor to get academics to churn out as many publications in as little time as possible. Indeed, this is sometimes stated overtly as the sole purpose of writing retreats (Kornharber, Cross, Betihavas and Bridgman 2016; McGrail, Rickard and Jones 2006).

This article considers the implications of such requirements, and the effects that performativity and productivity in relation to publication at writing retreats may have on scholarship. It also proposes an alternative way of viewing and conducting writing retreats. This alternative is in the form of a Slow scholarship, which originated in the Slow food movement, and which has been replicated in architecture, urban life and personal relations. Slow scholarship and pedagogies have been brought to attention in academia by writers such as the French chemist and Deleuzian scholar, Isabelle Stengers (2005; 2011) who has argued for Slow science. A Slow scholarship in the form of pedagogy has been further considered by writers such as Yvonne Hartman and Sandy Darab (2012), as well as by Maggie Berg and Barbara Seeber (2016) and Luke Martell (2014), who have also written more globally about the Slow academy and university. Slow scholarship, including a Slow ontology for writing has been considered by Jasmine Ulmer (2016), and then in various disciplines or from different perspectives: Anita Garey, Rosanna Hertz and Margaret Nelson (2014) have written about Slow scholarship from a sociological perspective, Liza Grandia (2015) from an anthropological perspective, Michael Silk et al. (2015) from a sports science perspective, from library science in the form of Slow Delphi, for research by Elizabeth Poirier and Lynn Robinson (2014) and from a feminist ethics of care by writers such as Allison Mountz et al. (2015).

Slow practices in reading and writing are those which encourage hesitation, thoughtfulness and new ways of relating, for readers and writers at writing retreats. These practices have also been referred to as the 'politics of slowness' or Slow scholarship, which is seen as being both political and historicized (Berg and Seeber 2016; Garey et al. 2014; Mountz et al. 2015; Stengers 2005; 2011; Ulmer 2016).

What we need, I argue in this article, is to re-imagine the writing retreat as an event where Slow scholarship can be practised using particular processes of reading and writing which would support this form of scholarship. In order to achieve Slow scholarship, I propose the use 
of a diffractive reading and writing methodology, as developed by Karen Barad (2007). Diffractive reading involves close, attentive and care-full readings of each other's work in order to affect and be affected as 'readerlywriters'2 'becoming-with'3 each other in writing retreats. This diffractive methodology of reading and writing can be regarded as part of a response-able pedagogy, where writers intra-act ${ }^{4}$ with each other in their mutual becomings as writers and readers. A response-able pedagogy incorporates the ability to affect and to be affected. Here I am using the concept 'affect' from a Spinozist viewpoint, rather than seeing affect as emotion in the everyday sense of the word (Massumi 2015). To affect and to be affected are not two capacities, as Brian Massumi reminds us, but they go together and refer to manoeuvrability, the 'where we might be able to go and what we might be able to do' in every present situation $(2015,8)$ - which, in this case, is with our writing and reading. Another way of putting this is to 'render each other capable' (Haraway 2016, 1) through 'becoming-with' our readings, writings and feedback to each other.

\section{STRUCTURE OF THE ARTICLE}

The article begins with a review of the context in which higher education currently finds itself, and elaborates on how the corporatization of the university has impacted on writing for publication. Since many of those writing about writing retreats have not addressed the consequences of marketization, and where they do, it is regarded as unproblematic, there is a lack of interrogation about how it affects the processes and practices of writing retreats. The following part of the article introduces the Slow movement and how scholarship may be differently undertaken as a Slow practice and ontology. The third part of the article considers how a Slow scholarship might be enacted at writing retreats through diffractive methodology, as an alternative reading of texts, in order to affect and to be affected as writers. The article illustrates what a Spinozist view of the politics of affect might involve and how this relates to the practice of reading and writing in order to become 'writerlyreaders' and 'readerlywriters' 5 This part of the article also offers an explanation of a diffractive methodology, as developed by Haraway and Barad, and how this diffractive methodology could be an instance of what might be considered as response-able pedagogical practices in academia (Barad 2007; Haraway 2016). The article provides some examples of this response-able pedagogy by examining the comments and responses given to each other in a small group on a writing retreat held in Cape Town.

The article concludes with a synthesis of how a response-able pedagogy for writing retreats which is embodied and accountable, and which is affective, might be made possible 
through a Slow scholarship ontology. It seeks to provide inventive provocations which may be taken forward as part of this response-able pedagogy. For example, it proposes that diffractive readings can productively lead to entangled thoughts and becomings for readerlywriters. One of the important aspects of such a pedagogy would be the facilitators of the workshop not seeing themselves as at a distance, or exterior to the process, but as intra-acting within the reading/writing entangled process through a collaborative material practice of developing insights, that could change and disturb more commonsense ways of viewing the writing retreat.

\section{THE CORPORATIZATION OF WRITING IN THE ACADEMY}

The corporatization of public life in the spirit of contemporary advanced capitalism (Braidotti 2013) and its associated neoliberal values, has affected public institutions across geopolitical contexts, with universities becoming increasingly swept into this trend of marketization (Silk et al. 2015). This corporatization of the academy has meant that market principles such as competitiveness, efficiency, excellence, consumerism, individualism and productivity now dominate all aspects of the university, including scholarship (Braidotti 2013; Berg and Seeber 2016; Shahjahan 2015). The ill-effects of this neoliberal rationality, in terms what is expected of academics, and practices that have been set up to accomplish these demands, have been welldocumented (Berg and Seeber 2016; Hartman and Darab 2012; Mountz et al. 2015; Nelson and Hertz 2014; Silk et al. 2015; Tabulawa 2016).

Research and scholarship has been at the forefront of concerns regarding performativity and production; at the same time teaching and administrative workloads have been extended and intensified in academia, as has the pressure to compete for funding grants (Hartman and Darab 2012; Mountz et al. 2015; Shahjahan 2015). This has been accompanied by an increasing trend towards casualization of teaching labour, increasing class sizes with dwindling resources in academia arising from budget cuts, resulting from reduced state funding of universities (Hartman and Darab 2012; Mountz et al. 2015). The consequences of such market forces have led to heightened expectations regarding productivity within shrinking time frames (Mountz et al. 2015). This has been able to go unchallenged through the creation of responsibilized selves and instrumentalized knowledge (Tabulawa 2016). These processes serve to normalize the loss of time for thinking about teaching, research and writing as scholarly practices, as academics adjust themselves to demanding schedules. This also happens because neoliberalism is premised on individualism, and the normative individual in academia is assumed to be white, middle class, rational, unencumbered and male. Many academics feel an embodied isolation regarding the demands made on them, and their failure to keep up with these (Braidotti 2013; 
Mountz et al. 2015).

The impetus to 'publish or perish', which has been described as 'speedy scholarship' (Hartman and Darab 2012, 53), may push academics on an ever faster spinning wheel of churning out meaningless publications to satisfy the numbers game set up by funding sources. On this dangerous route, writing retreats may fall into the trap of being one of the panoply of market-oriented technologies (Tabulawa 2016), to help accelerate academic publications for institutions to access the research funding which accompanies accredited publications (see for example Kornhaber et al.’s 2016 integrative review of the elements of writing retreats which increase publication outputs). The emphasis in these writing retreats is on the publication outcomes as product rather than on the process (McGrail, Rickard and Jones 2006; Nelson and Hertz 2014; Rosser, Rugg and Ross 2001). In this rush towards productivity in writing retreats, very little attention is paid to actively fostering pleasurable experiences, which have been found to be fundamental for productive writing to happen (Alaimo 2016; Nairn et al. 2015). The imbrication of corporate values in writing retreats leads to the hurry towards the production of articles, as is aptly summed up by Brian Massumi:

there is an imperative to produce and create what is increasingly being called, importing corporate vocabulary 'a deliverable' - a valorizable product ... like an article published in a standardized ('peer-reviewed’) disciplinary peer-reviewed journal (2015, 70-71).

This imperative to deliver means that academics are put under pressure to 'produce the goods' after a brief sojourn at a writing retreat. Paré (2010) remarks on how the rush to publication makes people less willing to take risks and engage in challenging and transformative writing endeavours. In his chapter which expresses his concerns about premature publication for doctoral students, Paré (2010) points out that writing is about joining a conversation in one's own discourse community. It takes time and attentiveness on the part of the supervisor to assist students to join ongoing conversations that happen in the writings of these discourse communities, as it requires a historical knowledge of how these conversations developed. The aspects of time and attentiveness are discussed in the following sections as being crucial parts of Slow scholarship, diffractive reading and a response-able pedagogy.

\section{SLOW SCHOLARSHIP}

The Slow movement (http://www.slowmovement.com/) was started in Italy with the publication of the Slow Food Manifesto in 1989, and initially focused on food, but then incorporated a resistance to other neoliberal markets, by focusing on Slow cities, Slow schools, 
Slow living Slow tourism, etc. The Slow movement embraces sustainability, emphasizing the political in the personal and an anti-corporate agenda (Grandia 2015). The Slow Science Academy (http://slow-science.org/), developed in 2010, calls for more time to think, to digest, and even to misunderstand each other in building a dialogue between the natural sciences and humanities. However, many authors contest the idea that the Slow movement is about doing things more slowly, arguing that it is rather about a way of creating a culture of care, of connecting with others and of reinvigorating and repoliticizing life, including academic life (Martell 2014; Mountz et al. 2015; Parkins and Craig 2006). Parkins and Craig (2006, ix) explain the Slow movement in the following way:

it is a process whereby everyday life - in all its pace and complexity, frisson and routine - is approached with care and attention ... an attempt to live in the present in a meaningful, sustainable, thoughtful and pleasurable way.

There are a number of important aspects to this definition for thinking about scholarship at writing retreats. Firstly, it acknowledges everyday life, which is important to remember when academics participate in writing retreats, as there are disruptions, and both paid and unpaid caring, and other responsibilities which affect the writing process (Garey, Hertz and Nelson 2014). The second significant aspect of Parkins and Craig's conception of the Slow movement is the foregrounding of care and attention, inspiring a strong ethic of engagement (Grandia 2015). As will be discussed later in the section on diffractive methodology, care, attentiveness and engagement are important qualities in the process of reading and writing, as well as the giving and receiving of feedback (see Bozalek, Bayat, Motala, Mitchell and Gachago 2016 for a fuller discussion on care ethics and feedback). Thirdly, the focus on living in the present coheres with a focus on the possibilities of focusing in depth on the processes of writing as they unfold. Finally, in order for a writing retreat to be conducive for engagement with quality work, it needs to be pleasurable and provide opportunities to connect with others in meaningful, thoughtful and sustainable ways (Alaimo 2016; Braidotti 2013). In addition to these considerations, Mountz et al. (2015) propose that Slow scholarship should address issues of privilege and marginalization in the academy, and strive towards making the university an inclusive place where all can collectively and collaboratively flourish. Slow scholarship also facilitates more time for dialogue, thought, and all the processes involved in creation - 'to think, write, read, research, analyze, edit, organize' (Mountz et al. 2015, 1236), to give and receive feedback, to intra-act and connect with others about their writing and their responses to one's own writing. Slow scholarship may also lead to unexpected reconfigurations of ideas - as 
Grandia (2015, 312) puts it:

Slow research embraces the power of serendipity (Hannerz 2006), allowing 'the unexpected to reconfigure the research itself' (Adams et al. 2014, 189), and, like Slow Food adherents who take pause before a meal, leaves ample space upfront for collaborative and dialogic engagement with communities.

The idea that an article can be written in a one off retreat and that those attending the retreat are monitored for the products that come out of these events (such as a publication in a journal) militates against quality time being spent in engaging with all the necessary processes discussed above. It also does not take into account the time it takes for ideas to percolate and mature, for thoughtful and meaningful work to be created.

\section{A DIFFRACTIVE METHODOLOGY FOR READING AND WRITING}

The notion of a diffractive methodology was initiated by Donna Haraway (1997; 2000; 2016) as an alternative to reflection and reflexivity, and taken forward by Karen Barad, a feminist philosopher and quantum physicist who refers to it as a 'physical phenomenon' which is part of wave behaviour - whether it is light, water, or sound waves. Diffraction is where waves 'combine when they overlap and the apparent bending and spreading out of waves when they encounter an obstruction' (Barad 2007, 28). In combining, waves can be amplified by being superimposed upon one another. Barad uses this physical process of diffraction as a methodology which engages affirmatively with difference. The valorization of difference as affirmative is important, as it gets away from replication and sameness, and emphasizes potential new insights that can come from the patterns of difference emanating from the diffractive process.

In a diffractive methodology the details of one text are read attentively and with care through another text in order to come to more creative insights. In a writing retreat, this might mean reading two theorists through each other, reading data through theoretical lenses, reading one person's writing through theories or through another person's writing, etc.

Barad (2007) proposes a diffractive methodology which is affirmative and gives due attention to the views, texts and theories that are read through each other, rather than critique, which she regards as a potentially epistemologically damaging process of distancing, othering and putting others down. A diffractive methodology in contrast, is not setting up one text against another but rather a detailed, attentive and care-full reading of the ideas of one through another, leading to more generative 'inventive and generative provocations' and the possibility of transdisciplinary intra-actions (Dolphijn and Van der Tuin 2012).

A diffractive analysis views difference from the standpoint of a relational ontology, that 
is, an effect of connections and relations within and between different bodies, affecting other bodies and being affected by them. This would mean that affect is important to understand from a Spinozist perspective, as made explicit in Brian Massumi’s (2015) work. Massumi’s ideas of affect are based on the following thinkers - Henri Bergson (intensities), Alfred North Whitehead, William James (connectedness), Gilbert Simondon, Felix Guattari and Gilles Deleuze. These are all are process philosophers who foreground change and 'becoming' and how the world is continually transforming and being re-made. Massumi (2015) uses a Spinozist view of affect which means what a body is able to do; he also refers to it as manoeuvrability it is not fixed; it refers to where a body can go or what it can do. According to Braidotti (2013), affects and passions are understood as 'the movements of the soul'. Affect is neither subjective nor objective; it is both enabling and constraining and is felt as such. Affect is also similar to Deleuze and Guattari's (1987) notion of the virtual, which refers to the potentials that exist out there: it is not what is actually there, but it is the potential that is there. That which is regarded as good from a feminist new materialist perspective is that which brings maximum potential and connection to the situation; (this is what is meant by 'becoming'); thus ethics happens between people, rather than inside them, and is pragmatic and situational (Massumi 2015).

Giving and receiving feedback in writing retreats in flattened rather than hierarchical relationships and across disciplinary boundaries provides a richness for diffractive readings and respondings, and opportunities for being affected by and affecting writing practices. Academic tradition generally requires a distance from the subject under question, where one viewpoint is pitted against another, and others' views might even be parodied. This dissatisfaction with critique expressed by Barad in her interviews (Dolphijn and van der Tuin 2012; Juelskjaer and Schwennesen 2012) has resonances with Bruno Latour's (2004) suggestion that 'critique has run out of steam'. Diffraction is proposed as an alternative to these sorts of critique, offering instead affirmative, detailed and care-full practices of reading and writing. Diffractive methodologies allow us to rethink practices at writing retreats - opening up and enabling practices that 'make a difference' (Barad) for becoming writers at these retreats. Diffraction draws attention to processual ways of affecting and being affected by each others' writing, showing how reading through the fine details of texts, with close and loving attentiveness, may provide an affirmative way of entangling ideas and engaging with the material-discursive ${ }^{6}$ to encounter differences that matter for the becoming of readerlywriters and writerlyreaders. An example of how such a response-able pedagogy has been attempted at a writing retreat is elaborated upon; Google Drive and face-to-face encounters were used as part of an apparatus ${ }^{7}$ as is discussed in the section below. 
In a response-able pedagogy, affect, the desire to learn (Juelskjær and Staunæs 2016) and becoming-with through rendering each other capable (Haraway, 2016), all work towards the possibility of flourishing as writerlyreaders and readerlywriters. Google Docs provides an appropriate tool in an online space for collaborative writing, where intertextual assemblages of making comments, responding to comments and making suggestions in the text are made possible. These affordances make Google Docs a conducive space for diffractive readings and writings to occur. Using such affordances for intra-action could be a way of cultivating a response-able pedagogy for writers at such retreats. Important for a response-able pedagogy is non-hierarchical intra-action between facilitators and participants in their giving feedback and receiving it from each other, through their co-presence in writing encounters on Google Docs. Since the affordance of replying to comments is different from other intertextual intra-actions such as on word-processed documents, the possibility exists for 'talking back' on the part of the participant and the facilitator too. ${ }^{8}$ This makes it possible for both participants and facilitators to become-with each other as writers and readers, and others who are witnessing the process in small groups also to benefit from the intra-actions.

\section{SOME EXAMPLES OF DIFFRACTIVE INTRA-ACTIONS}

The following examples are extracted from an inter-institutional writing retreat for academics across four higher education institutions, who had participated in a course on developing an educational research proposal; either one year or six months later, they were invited to attend a writing workshop to write about the research process and findings which had come from their initial proposals. Each facilitator followed through with the group members they had engaged with in the previous courses. The participants were provided with some inputs on conventions of writing abstracts, introductions, literature reviews, findings and conclusions in educational research, interspersed with periods for writing and for commenting on each others' texts in Google Docs, including their facilitator's text of her own writing. The reason that both facilitators and participants were involved in the processes of writing, reading and commenting on each others' work was so that all could learn from each other - each would have the opportunity to both affect and be affected by the other. Another advantage was that small group members could view each others' writings and comments and gain from the multiple perspectives that this provided. Below are some examples of comments given and responses to them, and the pieces of writing to which they responded. 


\section{EXAMPLE 1 - Participant 1 and 2 respond to facilitator's writing}

\section{Facilitator's text}

The South African example of socially just higher education pedagogy will focus on an interdisciplinary inter-institutional course which brought together students and lecturers across differently placed higher education institutions. The use of participatory learning and action (PLA) techniques as a way of engaging both with issues of social justice and of practising a socially just pedagogy will be considered from a critical posthuman and new feminist materialist perspective.

\section{Participant 1 comment_on facilitator's writing piece}

The territory is clearly defined. The 'niche' and the 'occupying of the niche' of critical posthuman and new feminist materialistic perspective, using PLA techniques are strong.

The above excerpt is an example of a diffractive reading and commenting - where there had been input at the writing retreat on Swales' CARS model (Create A Research Space), an approach recommended by Kamler and Thomson (2014). Swales identifies rhetorical moves in the genre of introduction, including how to identify a territory and create and occupy a research niche. Participant 1 has read this text/input through the facilitator's text on Google Docs and commented on it.

\section{Participant 2 comment on facilitator's writing piece on Google Docs:}

\section{Facilitator's text}

Barad (2007) refers to her notion of agential realism as an ethico-onto-epistemological framework. Difference is celebrated as productive rather than seen as alterity. Matter is seen as vital and vibrant and as having agency and as being mutually constituted with the discursive - as materialdiscursive (Barad 2007). This paper will consider the potential that these ways of viewing the world have for socially just higher education pedagogies.

\section{Participant 2 comment on facilitator's text above}

New paragraph here? It’s very dense reading!

\section{Facilitator's text}

For example, how does the mutual engagement and interconnections between students and teachers, matter and discourse, nature and culture, books and digital data, curriculum content and students' subjectivities play out in a socially just higher education pedagogy?

\section{Participant 2 comment on facilitator's text above on Google Docs}

At last, an example!: but the dualities and scenarios pitted here are so broad! Can you bring it more concretely, perhaps?

Facilitator's text: ... their impact on teaching and learning generally in higher education is limited. 


\section{Participant 2 comment:}

What reasons could you advance for this?

\section{Facilitators' text on Google Docs:}

Many higher education pedagogies are predicated upon taken-for-granted assumptions about the subject of knowledge, based on essentialized characteristics of a category broadly defined as 'students'. Most academic learning also rests on universalized notions of the structure of disciplinary knowledges as fixed entities which exist within strict disciplinary boundaries and which exercise discursive power within self-defined frames.

Participant 2 comment on facilitator's text above: Are you the only person to say so?

Facilitator's text: written about socially just pedagogies on critical posthumanism

Participant 2 comment on facilitator's text above: This phrase doesn't make sense as it stands - should 'on' be 'or' or perhaps socially just pedagogies from a critical posthumanist perspective ...?

In the examples above, it is clear that Participant 1 has been able to identify rhetorical moves that should happen in an introduction (identifying a territory, creating a niche, and occupying the niche) (Kamler and Thomson 2014), and she is able to diffract these moves through the text written by the facilitator. What is also clear from Participant 2's comments is that she is completely at ease in challenging and making provocative comments to the facilitator, indicating that it is a transversal relationship and that the facilitator does not necessarily occupy a position of authority in the intra-actions. Some of the comments by Participant 2 could be construed as fitting more of a 'critical' approach than a diffractive one, such as the comment 'it is too dense', in that it states explicitly what is wrong. However, the transversal nature of the relationship - where the participant is assuming authority and the facilitator is receiving comments from the participant - is unusual, and could be seen as diffractive. The participant was engaging in a careful and attentive reading of the facilitator's text from a transdisciplinary position (she is a librarian who has a background in music), creating provocations and interferences for the facilitator to think about, in order to open a window for alternative formulations. The advice of Participant 1 to interfere with the density of the text could be seen as a way of advising a diffractive process, of spreading out the text (waves) when it hits an obstacle. The diffractive intertextual comments can contribute to ways of cultivating Slow scholarship through their dialogical intra-actions and potential for improving the quality of the text. 
EXAMPLE 2 - Facilitator responds to Participant 2 who 'talks back'

\section{First interchange}

Participant 2 Text:

This is the negotiation of learning to become a participant in an academic process that Morrow originally described as 'epistemological access'. ${ }^{9}$ The ACRL Framework articulates spaces for such negotiations through disciplinary knowledge practices.

Facilitator comment: How does epistemological access relate to the ontological turn?

Participant 2 Response to comment: I was hoping that the foregoing had already addressed the inter-connection of these. Barnett doesn't dismiss knowledge and skills but notes that knowledge has been demoted. We are still working within a constructivist approach which implies that students will build their understanding with scaffolding.

\section{Second interchange}

Participant 2 Text: From the standpoint of a librarian, an important foundation of graduate attributes is the notion of lifelong learning that is the end-goal for any programme for information literacy.

Facilitator comment: You haven’t said much about life-wide learning which you mentioned initially

Participant 2 Response to comment: Well spotted! It's not a phrase that I tend to use. I noticed it appearing in Shirley Walters' work. I'm not entirely clear about it but think it refers to that collapsing of the private/public, social/professional compartments as I cited from Beetham.

In Example 2, the interchanges between Participant 2 and facilitator again illustrate the relaxed and egalitarian relationship between facilitator and respondent. Participant 2 is open and highly responsive and attentive to comments made on her text. She feels free to contest positions, offer further illumination on the issues mentioned and acknowledge the facilitator for flagging issues that were not apparent to her. The openness of the intra-action is apparent in these interchanges.

\section{EXAMPLE 3 - Interchange between participants with each other, and facilitator with participants}

\section{Participant 1 Text:}

The International Classification of Functioning, Disability and Health are used as the international framework to describe health and health-related issues (2001).

\section{Participant 2 comment:}

Does this framework also work with the Capability approach? What is the relationship between 
these two approaches? Maybe link this in some way or else introduce the Classification as the dominant tool (if this is the case) that you would like to mediate with the Capability approach.

\section{Participant 1 Text:}

...holistic approach to the concept of well-being and not merely in the context of sick vs. healthy (Shier and Graham, 2015).

\section{Participant 2 comment:}

Nice distinction. Are there any other writers before 2015 that dealt with this?

\section{Participant 1 Text:}

Some students find it difficult to relate to the Health Care module in social work education as they are usually young and might struggle to deal with the whole concept of disability,

\section{Facilitator comment:}

Do these necessarily relate - young and not being able to understand disabilities? Many young people are struggling with learning disabilities for instance which are undisclosed. What evidence is there that advanced age actually improves one's understanding of disability?

The above interchanges in Example 3 between participants with each other, and facilitator with participants, shows further provocative questions asked by both Participant 2 and facilitator, which might lead the participant to consider new directions in her writing.

All three examples show how inventive ways of re-imagining the writing can be created through intra-actions between participants themselves, and with the facilitator, in flattened rather than hierarchical relationships. The collaborative processes of writing and reading each others' texts, and responding to these could be seen as creating relationships and informing practices. As expressed by Pensoneau-Conway et al. $(2014,314)$ in their description of their collaborative writing endeavour:

Our collaboration demonstrated how my word choices, expressions, sentences, paragraphs, and arguments were read, negotiated, and interpreted by a reader, my writing partner. Our collaboration embodies and affirms how such writing practices create and inform important relationships.

\section{DISCUSSION AND CONCLUSION}

All the examples referred to in the section above, of bits of text and comments/replies of two participants and the facilitator, were emblematic of 'intertextual entanglements' (Truman 2016, 92). In Sarah Truman's project, she requested each of the participants by email to annotate the text in the margins, or 'intertextually entangle' with the text (in a similar vein to the Google Docs texts and comments at the writing retreat); these she called writerly texts (after Roland 
Barthes 1974), as they destablised expectations, expecting readers to write on the text while reading it. These interjections and practices between participants and facilitators at writing retreats are ways to become-with each other as readerlywriters and writerlyreaders. PensoneauConway et al. (2014), describing their collaborative writing, similarly found that 'One can be one's own reader; the act of reading can also be the act of writing; the text is inseparable from the assemblage of reader/reading and writer/writing'.

Donna Haraway (2016) uses the concept becoming-with as the way in which '[o]ntologically heterogeneous partners become who and what they are in material-semiotic worlding' (Haraway 2016, 12-13) and are rendered capable through each other. Translating this for intra-actions between various participants and facilitators and the texts they are working on, means that they come into being and are able to do things (are rendered capable) through the intertwined material-semiotic worldings.

The diffractive reading of each others' texts through the literature on writing for publication genres, the comments and responses to the comments, provide enabling constraints and constraining enablements for transformations and multiple reworkings of the texts. In other words, the participants and facilitators have the possibility of becoming readerlywriters and writerlyreaders through their intra-actions with the texts, comments and visceral face-to-face discussions of the texts in small groups. These practices could be considered to be part of a response-able pedagogy, which requires an openness to the world, an activeness in the world and a patience for the response in encounters and events; this is similar to what Massumi (2015) describes as what it means to affect and be affected. A response-able pedagogy is also inclined towards the maximum connection possible between the entangled parties, and bringing potential to the task at hand, rendering all parties capable. This kind of pedagogy is transversal in the sense of cutting across the usual categories of subject/object, facilitator/participant, body/mind, material/discursive in the collective encounter of reading/writing texts. The attentive, care-full and detailed reading of each others' work on Google Docs through various other texts and conversations, provide the affordances to learn again through each other, and may generate provocations for new and creative ideas for our readings and writings. A diffractive reading involves looking for differences which make a difference - they are affirmative and response-able engagements. There is also a lack of criticism or judgement, but a generosity to generate inventive ideas for reading/writing.

This is what a diffractive methodology makes possible for enacting a response-able pedagogy as part of a Slow scholarship. Perhaps a Slow scholarship at writing retreats needs to foreground other things than pushing people to publish prematurely, or pretending that a text 
can be written in a compressed time period. A Slow scholarship at writing retreats would emphasize the entanglement of the material/discursive, the ability to affect and be affected, transversality and the possibilities for creative, collaborative and response-able encounters. These encounters would include pleasurable activities such as walking, swimming, sharing food and wine, intra-acting with nature/cultures (Alaimo 2016; Ulmer 2016) while rendering each other capable as readerlywriters and writerlyreaders (Gale, Martin, Sakellariadis, Speedy and Spry 2012). These practices would assist with a move away from the corporate values of possessive individualism, competition and calculable performativity, which interpolate academics to anxiously 'enumerate and self-audit' their scholarship today (Mountz et al. 2015, 1243). It would also mean a move away from instrumentalizing writing, to seeing it as an ethical practice of affecting and being affected, of becoming-with each other as readerlywriters and writerlyreaders. Writing retreats could similarly be collective, inspirational and creative experimental events, entangled with practices of giving and receiving. In order to sustain response-able pedagogies in writing retreats, due attention should be paid to the preparation needed to benefit from a writing retreat, and the collective follow up in modes which are helpful for readers and writers.

\section{ACKNOWLEDGEMENTS}

I would like to acknowledge the reviewers for their care-full reading of my manuscript, their diffractive comments which greatly enhanced the quality of the manuscript. I would also like to acknowledge Joan Tronto, who fortuitously happened to be in South Africa at the time of my rewriting this article. She listened attentively to me reading parts of the text and reviewers' comments aloud and responded with thoughtful and provocative comments which mattered. This led me to see aspects of the text differently and make creative changes to the manuscript.

\section{NOTES}

1. A number of expected and unexpected disruptions influenced the writing of this article as well as an immersion in exploring, reading, thinking - with and through, connecting with and writing the ideas expressed in this article (see Nelson and Hertz 2014 for a discussion of the value of the unanticipated, the disruptive, for reaching different and new ways of thinking for Slow scholarship). The view of Slow Scholarship as being about doing things more slowly is contested in this paper and elsewhere, but this slowness was certainly the case in creating this manuscript. Hopefully, other qualities associated with Slow scholarship discussed in this article also come to the fore as the reader intra-acts with it. I am grateful to the reviewers of this article for their diffractive interferences, sparking my imagination and contributing to improving the quality of the writing - in other words towards its contribution towards Slow scholarship.

2. Sarah Truman uses the word 'writerly' when referring to writing in the margins of texts. She describes these intertextual intra-actions in the following way, which I find helpful for my argument for readerlywriters 'A writerly text destabilizes readers' expectations and requires them 
to 'write' the text while 'reading' it.'

3. Donna Haraway uses the concept becoming-with as the way in which '[o]ntologically heterogeneous partners become who and what they are in material-semiotic worlding' (Haraway 2016, 12-13) and are rendered capable through each other. This is similar to Barad's notion of intra-action which assumes that entities or people become through their entanglements with each other - individuals do not pre-exist their relationships. This means that in writing retreats we become with each other and with the tools we use, such as books, articles, online spaces, others' writing, etc.

4. Intra-action, a neologism created by Karen Barad (2007) is to be distinguished from interaction, which assumes separated individuals communicating with each other. Intra-action does not assume entities' pre-existing relationships but assumes that individual entities come into being through relationships. So becoming readerly-writers and writerly-readers would happen through an entanglement of ideas in such a relational ontology.

5. These neologisms are my own attempts to bypass the binary dualism of reading and writing which I argue are both necessary for a diffractive response-able pedagogy.

6. Material-discursive is another Baradian neologism which entangles matter and what matters with the discursive - the meanings of concepts and things are imbricated in each other and cannot be separated from one another.

7. An apparatus from Barad's (2007) perspective is not that which is generally thought of from a scientific or common sense view. It pertains not to an instrument for observation or a thing, but rather a doing. Barad (2007) sees apparatuses as open-ended practices which create boundaries. More specifically, apparatuses refer to 'specific material arrangements and material-discursive practices, which provide determinate meanings for concepts and things, entailing exclusions to make them intelligible, in this way 'enacting what matters and what is excluded from mattering' (Barad 2007, 148).

8. Although Google Docs offers affordances for dialogical interchanges and thus less hierarchical encounters between collaborators, it does not follow that all interchanges are necessarily more egalitarian.

9. Wally Morrow. 2009. Bounds of democracy: Epistemological access in higher education. Cape Town: Human Sciences Research Council, 78.

\section{REFERENCES}

Alaimo, S. 2016. Environmental politics and pleasure in posthuman times. Minneapolis: University of Minnesota Press.

Barad, K. 2007. Meeting the universe halfway: Quantum physics and the entanglement of matter and meaning. Durham: Duke University Press.

Berg, M. and B. K. Seeber. 2016. The slow professor: Challenging the culture of speed in the academy. Toronto: University of Toronto Press.

Bozalek, V., A. Bayat, S. Motala, V. Mitchell and D. Gachago. 2016. Diffracting socially just pedagogies through stained glass. South African Journal of Higher Education 30(3): 201-218.

Braidotti, R. 2013. The posthuman. Cambridge: Polity Press.

Deleuze, G. and F. Guattari. 1987. A thousand plateaus: Capitalism and schizophrenia. Trans. and foreword by Brian Massumi. Minneapolis and London: University of Minnesota Press.

Dolphijn, R. and I. van der Tuin. 2012. New materialism: Interviews and cartographies. University of Michigan Library: Open Humanities Press.

Gale, K., V. Martin, A. Sakellariadis, J. Speedy and T. Spry. 2012. Collaborative writing in real time. Cultural Studies $\leftrightarrow$ Critical Methodologies 12(5): 401-407.

Garey, A., R. Hertz and M. K. Nelson. (Eds.). 2014. Open to disruption: Time and craft in the practice of Slow sociology. Nashville: Vanderbilt University Press. 
Grandia, L. 2015. Slow ethnography: A hut with a view. Critique of Anthropology 35(3): 301-317.

Grant, B. 2006. Writing in the company of other women: Exceeding the boundaries. Studies in Higher Education 33(4): 483-95.

Haraway, D. 1997. Modest_Witness@Second_Millenium: FemaleMan_Meets_OncoMouse: Feminism and Technoscience. New York: Routledge.

Haraway, D. 2000. How like a leaf: An interview with Thyrza Nichols Goodeve. New York and London: Routledge.

Haraway, D. 2016. Staying with the trouble: Making kin in the Chthulucene. Durham and London: Duke University Press.

Hartman, Y. and S. Darab. 2012. A call for Slow scholarship: A case study on the intensification of academic life and its implications for pedagogy. Review of Education, Pedagogy, and Cultural Studies 34(1-2): 49-60.

Juelskjaer, M. and N. Schwennesen. 2012. Intra-active entanglements: An interview with Karen Barad. Kvinder, Koen og Forskning 21(1-2): 10-23.

Juelskjær, M. and D. Staunæs. 2016. Orchestrating intensities and rhythms: How Post-Psychologies are assisting new educational standards and reforming subjectivities. Theory and Psychology 26(2): 182-201.

Kamler, B. and P. Thomson. 2014. Helping doctoral students to write: Pedagogies for supervision. London and New York: Routledge.

Knowles, S. and B. Grant. 2014. Walking the labyrinth: The holding embrace of academic writing retreats. In Writing groups for doctoral education and beyond, ed. C. Aitchison and C. Guerin, 110-127. London and New York: Routledge.

Kornhaber, R., M. Cross, V. Betihavas and H. Bridgman. 2016. The benefits and challenges of academic writing retreats: An integrative review. Higher Education Research and Development. DOI: 10.1080/07294360.2016.1144572.

Martell, L. 2014. The slow university: Inequality, power and alternatives. Forum: Qualitative Social Research 15(3). http://www.qualitative-research.net/index.php/fqs/article/view/2223/3692/ (accessed 10 October 2016).

Massumi, Brian. 2015. Politics of affect. Cambridge: Polity.

McGrail, M., C. M. Rickard and R. Jones. 2006. Publish or perish: A systematic review of interventions to increase academic publication rates. Higher Education Research and Development 25(1): 1935. DOI: 10.1080/07294360500453053.

Moore, S. 2003. Writers' retreats for academics: Exploring and increasing the motivation to write. Journal of Further and Higher Education 27(3): 333-342.

Mountz, A., A. Bonds, B. Mansfield, J. Loyd, J. Hyndman, M. Walton-Roberts, R. Basu, R. Whitson, R. Hawkins, T. Hamilton and W. Curran. 2015. For Slow scholarship: A feminist politics of resistance through collective action in the neoliberal university. ACME: An International EJournal for Critical Geographies 14(4): 1235-1259.

Murray, R. 2015. Writing in social spaces: A social processes approach to academic writing. London and New York: Routledge.

Murray, R. and S. Moore. 2006. The handbook of academic writing: A fresh approach. Maidenhead: Open University Press.

Nairn, K., J. Cameron, M. Anakin, A. Juntrasook, R. Wass, J. Sligo and C. Morrison. 2015. Negotiating the challenge of collaborative writing: Learning from one writing group's mutiny. Higher Education Research and Development 34(3): 596-608. DOI: 10.1080/07294360.2014.973383.

Nelson, M. K. and R. Hertz. 2014. On being open to disruption. In Open to disruption: Time and craft in the practice of Slow sociology, ed. A. Garey, R. Hertz and M. K. Nelson, 1-18. Nashville: Vanderbilt University Press. 
Paré, A. 2010. Slow the presses: Concerns about premature publication. In Publishing pedagogies for the doctorate and beyond, ed. C. Aitchison, B. Kamler and A. Lee, 30-46. London and New York: Routledge.

Parkins, W. and G. Craig. 2006. Slow living. Oxford: Berg.

Pensoneau-Conway, S. L., D. M. Bolen, S. Toyosaki, C. K. Rudick and E. K. Bolen. 2014. Self, relationship, positionality, and politics: A community autoethnographic inquiry into collaborative writing. Cultural Studies $\leftrightarrow$ Critical Methodologies 14(4): 312-23.

Poirier, E. and L. Robinson. 2014. Slow Delphi: An investigation into information behaviour and the Slow movement. Journal of Information Science and Engineering 40(1): 88-96.

Rosser, S., D. L. Rugg and M. W. Ross. 2001. Increasing research and evaluation productivity: Tips for successful writing retreats. Health Promotion Practice 2(1): 9-13.

Shahjahan, R. A. 2015. Being 'lazy' and slowing down: Toward decolonizing time, our body, and pedagogy. Educational Philosophy and Theory 47(5): 488-501.

Silk, M., J. Francombe-Webb, E. Rich and S. Merchant. 2015. On the transgressive possibilities of physical pedagogic practices. Qualitative Inquiry: QI 21(9): 798-811.

Stengers, I. 2005. Deleuze and Guattari’s last enigmatic message. Angelaki 10(2): 151-167.

Stengers, I. 2011. 'Another science is possible!' A plea for Slow science. Faculté de Philosophie et Lettres, ULB, Inaugural lecture; Chair Willy Calewaert 2011-2012 (VUB).

Tabulawa, R. 2016. On inter-disciplinarity as political technology: How academics find themselves between a rock and a hard place. Keynote address at the South African Education Research Association, Cape Town, 23-26 October 2016.

Truman, S. 2016. Intratextual entanglements: Emergent pedagogies and the productive potential of texts. In Pedagogical matters: New materialisms and curriculum studies, ed. N. Snaza, D. Sonu, S. E. Truman and Z. Zaliwska, 91-108. New York: Peter Lang.

Ulmer, J. B. 2016. Writing slow ontology. Qualitative Inquiry, ahead of print 1-1. 